\title{
Corrigendum: Evolving strategies for cancer and autoimmunity: back to the future
}

\section{Peter J. L. Lane*, Fiona M. McConnell, Fabrina M. Gaspal, Maher G. Nawaf, David R. Withers and Graham Anderson}

MRC Centre for immune Regulation, Birmingham Medical School, Birmingham, UK

${ }^{*}$ Correspondence: p.j.l.lane@bham.ac.uk

Edited and reviewed by:

Fang-Ping Huang, Imperial College London, UK

Keywords: CD4T cell, autoimmunity, tolerance mechanisms, cancer, regulation, memory

\section{A corrigendum on}

Evolving strategies for cancer and autoimmunity: back to the future

by Lane PJL, McConnell FM, Anderson

G, Nawaf MG, Gaspal FM and Withers DR (2014). Front. Immunol. 5:154. doi:10. 3389/fimmu.2014.00154

The order of the authors for the article "Evolving strategies for cancer and autoimmunity: back to the future" should be as follows: "Peter J. L. Lane, Fiona M. McConnell, Fabrina M. Gaspal, Maher G. Nawaf, David R. Withers, Graham Anderson."

Conflict of Interest Statement: The authors declare that the research was conducted in the absence of any commercial or financial relationships that could be construed as a potential conflict of interest.

Received:30 May 2014; accepted: 02 June 2014; published online: 13 June 2014.

Citation: Lane PJL, McConnell FM, Gaspal FM, Nawaf MG, Withers DR and Anderson G (2014)
Corrigendum: Evolving strategies for cancer and autoimmunity: back to the future. Front. Immunol. 5:286. doi: 10.3389/fimmu.2014.00286

This article was submitted to Tumor Immunity, a section of the journal Frontiers in Immunology.

Copyright $\odot 2014$ Lane, McConnell, Gaspal, Nawaf, Withers and Anderson. This is an open-access article distributed under the terms of the Creative Commons Attribution License (CC BY). The use, distribution or reproduction in other forums is permitted, provided the original author(s) or licensor are credited and that the original publication in this journal is cited, in accordance with accepted academic practice. No use, distribution or reproduction is permitted which does not comply with these terms. 